\title{
Pengabdian Masyarakat di Era Pandemi Covid-19 di Curugbitung Nanggung Bogor
}

\author{
Salwa Aini Febrianti, Dedi Junaedi \\ IAI Nasional Laa Roiba Bogor \\ salwaaini02@gmail.com,dedijunaedi@laaroiba.ac.id
}

\begin{abstract}
The Community Empowerment Program is a form of student service for the community. This year the PPM implementation is different from the previous year due to the impact of Covid-19. This year's PPM aims to provide opportunities for students how students can participate in building public awareness for the prevention of Covid-19 transmission and provide public understanding to enter the New Normal while still complying with the Covid-19 health protocol and the provisions of life behavior during the New Normal. For two months, PPM activities carried out included: population data collection, counseling about the dangers of Covid-19, socializing the importance of maintaining cleanliness and health during the pandemic, distributing masks and providing information on the importance of wearing masks, as well as interviews about the impact of Covid-19 on the economy of the community. trader.
\end{abstract}

Keywords: Community Empowerment Program, Covid-19 Management, Curug Bogor

\section{ABSTRAK}

Program Pemberdayaan Masyarakat adalah salah satu bentuk pengabdian dari mahasiswa untuk masyarakat. Tahun ini pelaksanaan PPM berbeda dengan tahun sebelumnya karena terdampak Covid-19. PPM tahun ini bertujuan untuk memberikan kesempatan kepada mahasiwa bagaimana mahasiswa dapat berperan serta dalam membangun kesadaran masyarakat untuk pencegahan dari penularan Covid-19 dan memberi pemahaman masyarakat untuk memasuki New Normal dengan tetap mematuhi protokol kesehatan Covid-19 dan ketentuan perilaku hidup masa New Normal. Selama dua bulan, kegiatan PPM yang dilakukan antara lain: pendataan penduduk, penyuluhan tentang bahaya Covid-19, pensosialisasian pentingnya menjaga kebersihan dan kesehatan di masa pandemi, pembagian masker dan memberikan informasi pentingnya memakai masker, serta wawancara perihal dampak Covid-19 terhadap ekonomi para pedagang.

Kata Kunci: Program Pemberdayaan Masyarakat, Penaanggulangan Covid-19, Curug Bogor 


\section{El-Mujtama: JurnalPengabdian Masyarakat \\ Vol 2 No 1 (2022) 74-91 P-ISSN2746-9794E-ISSN2747-2736 \\ DOI: 10.47467/elmujtama.v12i1.542}

\section{PENDAHULUAN}

\section{Latar Belakang}

Institut Agama Islam Nasional (IAIN) Laa Roiba sebagai Perguruan Tinggi memiliki komitmen untuk memenuhi tuntutan dan dinamika kebutuhan masyarakat yakni bahwa ilmu, sikap dan keterampilan civitas akademiknya harus dapat diamalkan secara nyata di masyarakat.Program Pemberdayaan Masyarakat (PPM) merupakan wujud dari komitmen tersebut sebagai program akademika terpadu dalam Tri Dharma Perguruan Tinggi yang kegiatanya dilaksanakan di masyarakat secara nyata.

Penyelenggaraan PPM IAI Nasional Laa Roiba tahun 2020 ini, berbeda dari tahun sebelumnya, di situasi pandemi Covid-19 melanda dunia, Indonesia juga mengalami kondisi yang sama dimana seluruh masyarakat dan pemerintah sedang berupaya dalam pemutusan rantai penularan virus corona SARCov2 (Covid-19). Oleh karena itu KKN dinarasikan sebagai PPM Tematik Masa Pandemik Covid-19. Pandemi Covid-19 yang sangat tidak normal bagi dunia, berdampak buruk pada kesehatan, ekonomi, keamanan dan kehidupan sosial masyarakat. Pelaksanaan PPM pada tahun ini adalah berupa kegiatan studi lapangan yang dilakukan di lingkungan masing-masing mahasiswa dengan melakukan studi lapangan atau obseravasi,

Penyelenggaraan KKN masa Pandemik Covid-19 tahun 2020, membutuhkan perlakuan dan perhatian khusus, mengingat kegiatan dilaksanakan dalam koridor mengikuti Peraturan Penanggulangan Pencegahan Covid-19 dari Pemerintah, dimana pembelajaran harus dilakukan secara online, diterapkan penggunaan masker, diwajibkan menjaga jarak dan membiasakan perilaku hidup bersih dan sehat. Pedoman teknis ini dimaksudkan untuk memberi arahan dan panduan bagi semua pihak yang terlibat dalam kegiatan studi lapangan program PPM IAI Nasional Laa Roiba tahun 2020.

Program Pemberdayaan Masyarakat (PPM) adalah suatu kegiatan intrakulikuler wajib yang memadukan pelaksanaan Tri Dharma Perguruan Tinggi yakni Pendidikan, Penelitian dan Pengabdian Pada Masyarakat.Dengan metode pemberian pengalaman belajar dan bekerja kepada Mahasiswa dalam kegiatan pemberdayaan masyarakat.

Program Pemberdayaan Masyarakat (PPM) juga merupakan wahana penerapan serta pengembangan ilmu dan teknologi, dilaksanakan di luar kampus dalam waktu, mekanisme kerja dan persyaratan tertentu.Oleh karena itu, Program Pemberdayaan Masyarakat (PPM) diarahkan untuk menjamin keterkaitan antara dunia akademik 


\section{El-Mujtama: JurnalPengabdian Masyarakat \\ Vol 2 No 1 (2022) 74-91 P-ISSN2746-9794E-ISSN2747-2736 \\ DOI: 10.47467/elmujtama.v12i1.542}

teoritik dan dunia empirik praktik. Dengan demikain akan terjadi interaksi sinergis, saling menerima dan memberi, saling asah, asih dan asuh antara mahasiswa dan masyarakat.

Program Pemberdayaan Masyarakat (PPM) sebagai wadah pembelajaran, diharapkan dapat membuka akses komunikasi dan integrasi Civitas Akademika ke dalam masyarakat dengan titik tumpu pada bidang Ekonomi, Sosial Keagamaan, IPTEK, Seni dan Budaya sebagai basis kompetensi perguruan tinggi ini dengan memberikan respon terhadap kuatnya tekanan globalisasi terhadap lapisan masyarakat ekonomi lemah di Indonesia, yaitu pencapaian pengembangan kepribadian mahasiswa dan mengubah paradigma pembangunan (development) menjadi paradigma pemberdayaan (empowerment) sehingga kegiatan tersebut menjadi lebih aktualis.

Berdasarkan latar belakang di atas maka kami Mahasiswa Institut Agama Islam Nasional (IAIN) Laa Roiba yang diberikan tugas dari Kampus untuk melakukan pengabdian kepada masyarakat dengan mengamalkan setiap ilmu yang dimiliki dalam melaksanakan PPM dan merupakan suatu bentuk kegiatan yang dilaksanakan secara tidak langsung di lapangan karena kondisi pandemi Covid 19 melalui observasi tematik dan simulasi dengan memadukan teori yang diperoleh dengan kenyataan sebenarnya di masyarakat.

Maka berkenaan dengan hal tersebut pada tanggal 09 s/d 27 November 2020 dengan mengambil lokasi di Di Kampung Cibeber Kaum RT.02/07 Desa Curugbitung Kecamatan Nanggung Kabupaten Bogor.

\section{Tujuan}

Tujuan utama dari Program Pemberdayaan Masyarakat (PPM) adalah untuk memberikan pengalaman kepada mahasiswa dalam ke ikut sertaannya dalam proses pembangunan. Kegiatan ini diharapkan akan membuka wawasan mahasiswa dalam proses pematangan berfikir, bertindak, dan mengambil keputusan. Serta untuk berperan dalam membangun kesadaran masyarakat terhadap pencegahan covid-19.

Tujuan dari kegiatan Studi Lapangan Program PPM Masa Pandemik Covid-19 adalah:

1) Untuk memberikan kesempatan mahasiwa menerapkan ilmu pengetahuan dan sebagai inovator yang didapat di kampus untuk diaplikasikan ke masyarakat langsung. 


\section{El-Mujtama: JurnalPengabdian Masyarakat \\ Vol 2 No 1 (2022) 74-91 P-ISSN2746-9794E-ISSN2747-2736 \\ DOI: 10.47467/elmujtama.v12i1.542}

2) Untuk memberikan kesempatan kampus melalui PPM mahasiwa pada kondisi Pandemik Covid-19 berperan serta dalam membangun kesadaran masyarakat untuk pencegahan dari penularan Covid-19 dan memberi pemahaman masyarakat untuk memasuki New Normal dengan tetap mematuhi protokol kesehatan Covid-19 dan ketentuan perilaku hidup masa New Normal.

\section{Sasaran \\ Masyarakat dan Pedagang di Kampung Cibeber Kaum Rw 07 Desa Cururgbitung Kecamatan Nanggung Kabupaten Bogor.}

\section{Pihak yang terlibat dalam pendampingan}

Pihak-pihak yang terlibat dalam pendampingan antara lain :

1. Ketua RW 07

2. Ketua RT 02

3. Tokoh Masyarakat

4. Masyarakat setempat

5. Pedagang setempat

\section{METODE KAJIAN/PENELITIAN}

Metode kajian/pengabdian masyarakat yang digunakan adalah metode kajian deskriptif kualitatif dengan pendekatan pendekatan observasi, diskusi dan partisipasi. Wawancara, diskusi dan sosialisasi dilakukan dengan para pihak, serta diperkaya dengan kajian fenomologi social yang ditemukan selama kegiatan KKN (Kuliah Kerja Nyata) di Desa Karacak, Kecamatan Leuwiliang, Kabupaten Bogor dalam periode November - Desember 2020. Kegiatan yang dilajukan antara lain survey kesadaran dan pemahaman masyarakat tentang pandemic Covid19, sosialisasi dan penyadaran protocol Kesehatan, serta pemberdayaan masyarakat dalam era pandemi Covid-19. 


\section{El-Mujtama: JurnalPengabdian Masyarakat \\ Vol 2 No 1 (2022) 74-91 P-ISSN2746-9794E-ISSN2747-2736 \\ DOI: 10.47467/elmujtama.v12i1.542}

\section{GAMBARAN UMUM LOKASI PPM}

\section{A. Gambaran Keadaan Umum}

Desa Curugbitung adalah salah satu Desa yang terletak di Kecamatan Nanggung Kabupaten Bogor dengan Luas wilayah 1.156,17 Ha, terdiri dari 5 (lima) Wilayah Dusun, 14 (Empat belas) Rukun Warga (RW), dan 46 (Empat puluh Enam) Rukun Tetangga (RT). Desa Curugbitung merupakan kawasan pedesaan dengan cakupan perbukitan dalam ketinggian di atas permukaan laut sekitar $600-800 \mathrm{~m}$. suhu rata-rata diantara 26-34 "C dengan curah hujan berkisar antara 300-400 mm, dimana musim yang sering terjadi hanya musim Hujan dan kemarau.

Batas wilayah Desa Curugbitung adalah sebagai berikut :

1. Sebelah Utara berbatasan dengan Desa Nanggung dan Kecamatan Sukajaya

2. Sebelah timur berbatasan dengan Desa Bantarkaret dan Desa Pangkal Jaya

3. Sebelah selatan berbatasan dengan Desa Cisarua dan Desa Malasari

4. Sebelah Barat berbatasan dengan Desa Malasari.

Adapun orbitasi atau jarak tempuh dengan pusat pemerintahan adalah :

a. Jarak dengan Ibukota kecamatan $5 \mathrm{~km}$.

b. Jarak dengan Ibukota Kabupaten $67 \mathrm{~km}$.

c. Jarak dengan Ibukota Propinsi 162 Km.

\section{DATA KELEMBAGAAN PEMERINTAHAN DAN KEMASYARAKATAN}

\section{Jumlah Pemerintah/Perangkat Desa}

1 Kepala Desa

1 Orang

2 Sekretaris Desa

1 Orang

3 Kepala Seksi

3 Orang

4 Kepala Urusan

3 Orang

5 Unsur Wilayah / Kepala Dusun

6 Orang

6 Staf

1 Orang 


\section{El-Mujtama: JurnalPengabdian Masyarakat \\ Vol 2 No 1 (2022) 74-91 P-ISSN2746-9794E-ISSN2747-2736 \\ DOI: 10.47467/elmujtama.v12i1.542}

\section{Badan Permusyawaratan Desa (BPD)}

1. Jumlah Anggota BPD

9 Orang

\section{Kelembagaan Desa}

1. Jumlah Pengurus LPM

5 Orang

2. Kader PKK

14 Orang

3. Jumlah Ketua RW

14 Orang

4. Jumlah Ketua RT

46 Orang

5. Keamilan / P3.N

8 Orang

6. Satlak Penanggulangan Bencana (PB)

6 Orang

\section{LUAS WILAYAH BERDASARKAN PENGGUNAAN LAHAN}
a. Perumahan/pemukiman dan pekarangan
510,23 ha
b. Pesawahan
163,23 ha
c. Ladang / tegalan
315,20 ha
d. Perkebunan/Hak Guna Usaha
101,00 ha
e. Hutan Taman Nasional (TNGHS)
34,68 ha
f. Kolam/Tambak/Empang
0,10 ha
g. Sungai
h. Situ
2,00 ha
i. Jalan
20,00 ha
j. Sarana industri
k. Perkantoran
l. Pekuburan/pemakaman
7,50 ha 


\section{El-Mujtama: JurnalPengabdian Masyarakat \\ Vol 2 No 1 (2022) 74-91 P-ISSN2746-9794E-ISSN2747-2736 \\ DOI: 10.47467/elmujtama.v12i1.542}

\section{SEJARAH DESA CURUGBITUNG}

Belum dapat dipastikan tanggal dan tahun berdirinya Pemerintahan Desa Curugbitung. Demikian juga sejarah penamaan desa. Namun dari cerita lisan pinisempuh desa, diperoleh informasi bahwa kawasan administratif Desa Curugbitung sudah berjalan sejak masa Pemerintahan Hindia Belanda. Pada saat itu sistem pemerintahan desa masih berbentuk kamandoran yang kepalanya dikenal dengan sebutan "Mandor."

Pada masa pemerintahan hindia belanda, dapat diketahui bahwa struktur pemerintahan paling tinggi setingkat nasional dikepalai oleh Gubernur Jendral. Gubernur Jendral berfusngsi seperti perdana menteri yang mengepalai pemerintahan dan menjadi wakil dari kerajaan Nederland di wilayah Hindia Belanda atau disebutjuga Nederland Indie. Pemerintahan setingkat provinsi atau kegubernuran dipimpin oleh seorang resdiden. Adapun di wilayah kabupaten dipimpin oleh seorang Bupati pribumi yang kekuasaan pemerintahanya dikendalikan oleh seorang asisten residen, kemudian lebih lanjut pemerintahan di bawahnya adalah demang setingkat kecamatan, dan mandor atau kamandoran setingkat desa.

Mandor selain bertugas mengepalain desa, juga berfungsi sebagai pelaksana pengawasan lingkungan perkebunan ondernemer belanda. Diketahui bahwa sejak masa kolonial, wilayah desa curugbitung termasuk wilayah perkebunan, bahkan hingga saat ini 100,673 ha dari 1.156,17 ha wilayah Desa Curugbitung masih merupakan lahan perkebunan dalam bentuk Hak Guna Usaha, yang merupakan sisa dari pelaksanaan landreform tahun 1982.

Pada masa kolonial sampai dengan masa revolusi, pemerintahan desa dari muali bentuk kamandoran hingga bentuk pemerintahan desa, tidak memiliki kantor sebagaimana pada masa sekarang. Kegiatan mandor atau kepala desa dipusatkan di rumah/kediaman mandor atau kepala desa itu sendiri. Sehingga penamaan desa curugbitung dapat diperkirakan oleh karena mandor pertamanya bertempat tinggal di kampung curugbitung. Hal ini sejalan dengan cerita lisan masyarakat bahwa pda jaman dahulu terdapat seorang mandor bernama Mandor Sahawa yang bertempat tinggal di Kampung Curugbitung. Diperkirakan mandor sahawa inilah yang merupakan pendiri desa curugbitung. Adapun tahun dan periode kepemimpinannya belum dapat dipastikan.

VISI DAN MISI PEMERINTAH DESA CURUGBITUNG 2017-2023 


\section{El-Mujtama: JurnalPengabdian Masyarakat \\ Vol 2 No 1 (2022) 74-91 P-ISSN2746-9794E-ISSN2747-2736 \\ DOI: 10.47467/elmujtama.v12i1.542}

VISI

- Mewujudkan Desa Curugbitung Mandiri, Sejahtera, Demokratis, Aman, dan Berwibawa.

MISI

- Memaksimalkan fungsi pemerintahan desa sebagai pelayan masyarakat melalui tata kerja yang solid, efisien, efektif, dan partisipatif.

- Bersinergi dengan tokoh masyarakat, tokoh agama, lembaga-lembaga, dan seluruh elemen masyarakat untuk progresifitas pembangunan dan transformasi sosial.

- Menjaga stabilitas dan kondusifitas lingkungan melalui tata ruang desa dan penguatan sistem keamanan dan ketahanan lingkungan.

- Mengembangkan fasilitas dan memperluas akses masyarakat kepada peningkatan taraf pendidikan, ketahanan pangan, kesehatan, penguatan ekonomi, dan pemberdayaan perempuan.

- Menggali \& mengembangkan potensi alam, agraria, pariwisata, dan industri, untuk memperluas lapangan kerja dan penyerapan sumber-sumber investasi.

- Memperluas partisipasi perempuan dalam penguatan pemerintahan, pendidikan, sosial, ekonomi, dan budaya.

- Memperkuat basis kegiatan kepemudaan dan olahraga.

\section{Keadaan Demografi, Ekonomi, Sosial Dan Budaya}

Jumlah penduduk Desa Curugbitung sampai Bulan Oktober 2019 tercatat dari 2.850 Kepala Keluarga (KK), terdiri dari 5.5087 Laki-laki dan 5.318 Perempuan. Semua tercatat beragama Islam.

Tabel 1.1

Jumlah penduduk berdasarkan Struktur Umum

\begin{tabular}{|r|r|r|r|}
\hline \multirow{2}{*}{$\begin{array}{c}\text { Klasifikasi kelompok } \\
\text { Umur }\end{array}$} & \multicolumn{2}{|c|}{ Jumlah Jiwa } & \multirow{2}{*}{ 1. J u m l a h } \\
\cline { 2 - 3 } 0-12 Bulan & 75 & 77 & 152 \\
\hline 1-5 Tahun & 370 & 384 & 754 \\
\hline 5-12 Tahun & 569 & 398 & 967 \\
\hline 12-17 Tahun & 472 & 401 & 673 \\
\hline
\end{tabular}




\section{El-Mujtama: JurnalPengabdian Masyarakat}

Vol 2 No 1 (2022) 74-91 P-ISSN2746-9794E-ISSN2747-2736

DOI: 10.47467/elmujtama.v12i1.542

\begin{tabular}{|r|r|r|r|}
\hline 17-23 Tahun & 525 & 435 & 960 \\
\hline 23-30 Tahun & 771 & 634 & 1.405 \\
\hline $31-40$ Tahun & 957 & 986 & 1.943 \\
\hline $41-50$ Tahun & 628 & 729 & 1.357 \\
\hline 51-60 Tahun & 297 & 301 & 598 \\
\hline 61-65 Tahun & 238 & 248 & 598 \\
\hline 66-70 Tahun & 307 & 213 & 520 \\
\hline 70 Tahun > & 199 & 217 & 336 \\
\hline 2. J u m $\mathbf{~}$ a h & $\mathbf{5 . 5 0 8}$ & $\mathbf{5 . 3 1 8}$ & $\mathbf{1 0 . 8 2 6}$ \\
\hline
\end{tabular}

Sedangkan keadaan penduduk menurut Tingkatan Pendidikan sebagai berikut:

\begin{tabular}{|c|l|c|}
\hline No. & \multicolumn{1}{|c|}{ Tingkatan Pendidikan } & Jumlah Orang \\
\hline 1 & Tidak Tamat SD & 249 Orang \\
\hline 2 & Tamat SD & 1.582 Orang \\
\hline 3 & Tamat SLTP & 1.951 Orang \\
\hline 4 & Tamat SLTA & 1.661 Orang \\
\hline 5 & Tamat Akademi/D1,II,III & 185 Orang \\
\hline 6 & Tamat Perguruan Tinggi S.1/S.2/S.3 & 77 Orang \\
\hline
\end{tabular}

Adapun keadaan penduduk menurut Mata Pencaharian adalah :

\begin{tabular}{|c|l|c|}
\hline No. & \multicolumn{1}{|c|}{ Mata Pencaharian } & Jumlah Orang \\
\hline 1 & Petani dan Buruh Tani & 1.780 Orang \\
\hline 2 & Pedagang & 935 Orang \\
\hline 3 & Pegawai Negeri Sipil (PNS) & 26 Orang \\
\hline 4 & TNI & Orang \\
\hline 5 & POLRI & 35 Orang \\
\hline 6 & Peternak & 4 Orang \\
\hline 7 & Pengrajin & 26 Orang \\
\hline 8 & Pengusaha & 3 Orang \\
\hline 9 & Penjahit & 15 Orang \\
\hline 10 & Tukang Batu/Pasir & 20 Orang \\
\hline 11 & Tukang Kayu & 3 Orang \\
\hline 12 & Tukang Las & 142 Orang \\
\hline 13 & Tukang Ojeg & . \\
\hline
\end{tabular}




\section{El-Mujtama: JurnalPengabdian Masyarakat \\ Vol 2 No 1 (2022) 74-91 P-ISSN2746-9794E-ISSN2747-2736 \\ DOI: 10.47467/elmujtama.v12i1.542}

\begin{tabular}{|c|l|c|}
\hline 14 & Pengemudi & 51 Orang \\
\hline 15 & Pensiunan & 11 Orang \\
& $\bullet \quad$ Purnawirawan & - \\
& $\bullet \quad$ Veteran & - \\
\hline 16 & Nelayan $\quad$ Wirakawuri & - \\
\hline 17 & Guru Honor dan Sukwan & 56 Orang \\
\hline 18 & Wiraswasta & 1.018 Orang \\
\hline
\end{tabular}

\section{Keadaan Sosial Politik Dan Keamanan}

Tahun 2011 merupakan tahun politik bagi Desa Curugbitung. Pada tahun ini, tepatnya tanggal 13 Februari 2011, dilakukan pemilihan kepala Desa Curtugbitung yang melibatkan 6.308 pemilih. Pemilihan ini diikuti oleh tiga calon kepala desa dan salah satunya ialah kepala Desa incumbent, namun perolehan suaranya terkalahkan oleh calon kepala desa lain yang saat ini memerintah, yakni Bapak Engkos Kosasih.

Suhu politik pasca Pemilihan Kepala Desa masih terasa panas hingga akhir tahun 2011. Hal ini mengakibatkan kurang kondusifnya kegiatan pelayanan pemerintah Desa. Namun demikian Kepala Desa beserta jajarannya terus berupaya nelakukan pendekatanpendekatan dan konsolidasi ke kampong-kampung sehingga keadaan berangsur menjadi normal.

\section{Keadaan Sarana Dan Prasarana}

\section{Sarana Prasarana Pemerintahan Desa}

\begin{tabular}{|c|l|l|}
\hline No. & \multicolumn{1}{|c|}{ Prasarana } & \multicolumn{1}{c|}{ Jumlah } \\
\hline 1 & Kantor Desa & 1 Unit \\
\hline 2 & $\begin{array}{l}\text { Secretariat Bersama (BPD, LPM } \\
\text { dan KATAR) }\end{array}$ & 1 Unit \\
\hline 3 & Balai Dusun & - \\
\hline 4 & Aula Pertemuan & 1 Buah \\
\hline 5 & Pos Kamling & 30 Buah \\
\hline
\end{tabular}

\section{Sarana dan Prasarana Perhubungan Jalan}
1. Jalan Beton
1 Jalur
2. Jalan Hotmix
2 Jalur
3. Jalan Aspal
1 Jalur
4. Jalan Pengerasan
1 Jalur
5. Jalan Semenisasi / jalan lingkungan
40 Jalur 


\section{El-Mujtama: JurnalPengabdian Masyarakat \\ Vol 2 No 1 (2022) 74-91 P-ISSN2746-9794E-ISSN2747-2736 \\ DOI: 10.47467/elmujtama.v12i1.542}
6. Jalan Tanah
1 Jalur

3. Sarana dan prasarana Pendidikan umum
a. Paud
8 Buah
b. TK
2 Buah
c. SD Negeri
4 Buah
d. SLTP Terbuka dan Swasta
2 Buah
e. SLTA (SMU/SMK)
1 Buah
f. Tempat kursus
1 Buah

4. Sarana dan Prasarana Pendidikan Islam
1. TPA/TQA/RA
34 Buah
2. MI
2 Buah
3. Mts
2 Buah
4. MA
5. Pondok Pesantren
8 Buah
6. Majlis Ta'lim
21 Buah

5. Sarana dan Prasarana Peribadatan
a. Masjid
b. Mushola
c. Gereja
d. Wihara
e. Pura

18 Buah

28 Buah

6. Sarana dan Prasarana Kesehatan
1. Puskesmas / Puskes
1 Buah
2. Posyandu
15 Buah

7. Sarana dan Prasarana Perekonomian
1. Pasar Desa
1 Buah
2. KUD
3. Koperasi Non KUD
1 Buah
4. Wartel 


\section{El-Mujtama: JurnalPengabdian Masyarakat \\ Vol 2 No 1 (2022) 74-91 P-ISSN2746-9794E-ISSN2747-2736 \\ DOI: 10.47467/elmujtama.v12i1.542}

5. Counter HP

23 Buah

6. Kantor Pos

3. Pengecer Bensin

42 Buah

8. Bank Pemerintah

9. Bank Swasta

1 Buah

10. BPR

1 Buah

11. Terminal / sub terminal

1 Buah

12. Swalayan/Mini Market

4 Buah

13. Toko Sembako Skala Besar

13 Buah

14. Toko Pupuk / Alat Pertanian

1 Buah

15. Material

4 Buah

16. Warung Lansam

3 Buah

17. Counter Isi Ulang Air minum

6 Buah

18. ATM

19. Perbengkelan / Las

15 Buah

20. Toko Pakaian

12 Buah

21. POM Mini

6 Buah

8. Sarana dan Prasarana Olah Raga

1. Lapangan Sepak Bola

6 Buah

2. Lapangan Batminthon/Bulutangkis

3 Buah

3. Lapangan Tenis

4. Lapangan Basket

5. Lapangan Futsal

6. Tenis Meja

1 Buah

7. Kolam Renang

2 Buah 


\section{El-Mujtama: JurnalPengabdian Masyarakat \\ Vol 2 No 1 (2022) 74-91 P-ISSN2746-9794E-ISSN2747-2736 \\ DOI: 10.47467/elmujtama.v12i1.542}

\section{PROFIL DESA CURUGBITUNG}

\begin{tabular}{|c|c|c|c|}
\hline \multicolumn{4}{|c|}{ I. DATA WILAYAH ADMINISTRASI DESA } \\
\hline 1. & Kabupaten/Kota (Cantumkan Kode Wilayah) & : & Bogor (32) \\
\hline 2. & Kecamatan (Cantumkan Kode Wilayah) & : & Nanggung, (21) \\
\hline 3. & Desa (Cantumkan Kode Wilayah) & : & Curugbitung, (004) \\
\hline 4. & Alamat Kantor & : & $\begin{array}{l}\text { Jl. Ace Tabrani Km.10 Cibeber } \\
\text { RT.02/06 }\end{array}$ \\
\hline 5. & Jumah Kampung & : & 34 \\
\hline 6. & Jumlah RT. & $:$ & 46 \\
\hline 7. & Jumlah RW. & : & 14 \\
\hline 8. & Jumlah Dusun & $:$ & 6 \\
\hline \multirow{3}{*}{9.} & Jumlah Penduduk & : & 11.820 \\
\hline & Jumlah Penduduk Laki-laki (Jiwa) & $:$ & 6.235 \\
\hline & Jumlah Penduduk Perempuan (Jiwa) & $:$ & 5.589 \\
\hline 10. & Jumlah Kepala Keluarga (KK) & : & 3.404 \\
\hline 11. & Luas Wilayah & $:$ & 1.156,17 На. \\
\hline \multirow{4}{*}{12.} & Tingkat Perkembangan Desa & & Berkembang \\
\hline & Swadaya (Mula, Madya, Lanjut) & : & Madya \\
\hline & Swakarya (Mula, Madya, Lanjut) & : & Madya \\
\hline & Swasembada (Mula, Madya, Lanjut) & : & Madya \\
\hline \multicolumn{4}{|c|}{ II. DATA ADMINISTRASI PERANGKAT DESA TAHUN 2017} \\
\hline 1. & Nama Kepala Desa & : & Engkos Kosasih \\
\hline 2. & TMT Pelantikan & : & 25 April 2017 \\
\hline 3. & Pendidikan Terakhir Kepala Desa & : & S1 \\
\hline 4. & Handphone (HP) Kepala Desa & : & 085694547754 \\
\hline 5. & Nama Sekretaris Desa & : & Dede Taufiqurrohman \\
\hline 6. & Pendidikan Terakhir Sekretaris Desa & $:$ & S1 \\
\hline 7. & Status & : & \\
\hline
\end{tabular}




\section{El-Mujtama: JurnalPengabdian Masyarakat \\ Vol 2 No 1 (2022) 74-91 P-ISSN2746-9794E-ISSN2747-2736 \\ DOI: 10.47467/elmujtama.v12i1.542}

\begin{tabular}{|l|l|l|l|}
\hline & Pegawai Negeri Sipil (PNS) & $:$ & NIP.19 \\
\cline { 2 - 4 } & Non PNS & $:$ & NON PNS \\
\hline 8 & Golongan/Ruang & $:$ & \\
\hline 9. & Handphone (HP) Sekretaris Desa & $:$ & 085817422655 \\
\hline 10. & Pendidikan Terakhir & $:$ & \\
\hline 11. & Jumlah Perangkat Desa & $:$ & 8 \\
\hline 12. & Jumlah Anggota Badan Permusyawaratan Desa & $:$ & 11 \\
\hline
\end{tabular}

BAB III

\section{DESKRIPSI KEGIATAN}

A. Program Kegiatan yang akan dilakukan dan waktu pelaksanaannya

\begin{tabular}{|c|c|c|c|c|c|c|c|c|}
\hline $\begin{array}{l}\mathrm{N} \\
\mathrm{O}\end{array}$ & $\begin{array}{l}\text { Tgl/Bln } \\
\text { /Thn }\end{array}$ & Program & $\begin{array}{l}\text { Jenis } \\
\text { Kegiatan }\end{array}$ & Sasaran & Media & $\begin{array}{l}\text { Mitra } \\
\text { Kerja }\end{array}$ & $\begin{array}{l}\text { Sumber } \\
\text { dana }\end{array}$ & $\begin{array}{l}\text { Keteranga } \\
\mathrm{n}\end{array}$ \\
\hline 1. & $\begin{array}{l}10 / 11 / \\
20\end{array}$ & $\begin{array}{l}\text { Program } \\
\text { Pendataan } \\
\text { Penduduk }\end{array}$ & $\begin{array}{l}\text { Pendataan } \\
\text { Jumlah } \\
\text { Penduduk }\end{array}$ & $\begin{array}{l}\text { Masyara } \\
\text { kat, } \\
\text { Lembaga } \\
\text { disekitar }\end{array}$ & $\begin{array}{l}\text { Medso } \\
\text { s atau } \\
\text { yang } \\
\text { lainny } \\
\text { a }\end{array}$ & $\begin{array}{l}\text { RT/R } \\
\text { W/Sat } \\
\text { uan } \\
\text { Tugas } \\
\text { Covid- } \\
\text { 19) }\end{array}$ & $\begin{array}{l}\text { Mandiri } \\
\text { /Kerjas } \\
\text { ama } \\
\text { dengan } \\
\text { mitra }\end{array}$ & $\begin{array}{l}\text { Pengisian } \\
\text { Perencana } \\
\text { an }\end{array}$ \\
\hline 2. & $\begin{array}{l}14 / 11 / \\
20\end{array}$ & $\begin{array}{l}\text { Memberikan } \\
\text { informasi } \\
\text { kepada anak- } \\
\text { anak tentang } \\
\text { covid-19 }\end{array}$ & $\begin{array}{l}\text { Penyuluhan } \\
\text { tentang } \\
\text { covid-19 }\end{array}$ & $\begin{array}{l}\text { Anak- } \\
\text { anak di } \\
\text { kawasan } \\
\text { RW } 07\end{array}$ & $\begin{array}{l}\text { Medso } \\
\text { s atau } \\
\text { yang } \\
\text { lainny } \\
\text { a }\end{array}$ & $\begin{array}{l}\text { RT/R } \\
\text { W/Sat } \\
\text { uan } \\
\text { Tugas } \\
\text { Covid- } \\
\text { 19) }\end{array}$ & Mandiri & $\begin{array}{l}\text { Pengisian } \\
\text { Perencana } \\
\text { an }\end{array}$ \\
\hline 3. & $\begin{array}{l}21 / 11 / \\
20\end{array}$ & $\begin{array}{l}\text { Mengajarkan } \\
\text { pentingnya } \\
\text { menjaga } \\
\text { kebersihan } \\
\text { dan } \\
\text { kesehatan di } \\
\text { masa } \\
\text { pandemi }\end{array}$ & $\begin{array}{l}\text { Penyuluhan } \\
\text { dan } \\
\text { berolahraga } \\
\text { bersama } \\
\text { (senam) }\end{array}$ & $\begin{array}{l}\text { Anak- } \\
\text { anak di } \\
\text { kawasan } \\
\text { RW } 07\end{array}$ & $\begin{array}{l}\text { Medso } \\
\text { s atau } \\
\text { yang } \\
\text { lainny } \\
\text { a }\end{array}$ & $\begin{array}{l}\text { RT/R } \\
\text { W/Sat } \\
\text { uan } \\
\text { Tugas } \\
\text { Covid- } \\
\text { 19) }\end{array}$ & Mandiri & $\begin{array}{l}\text { Pengisian } \\
\text { Perencana } \\
\text { an }\end{array}$ \\
\hline 4. & $\begin{array}{l}24 / 11 / \\
20\end{array}$ & $\begin{array}{l}\text { Membagikan } \\
\text { masker dan } \\
\text { memsosialisa } \\
\text { sikan tentang } \\
\text { pentingnya } \\
\text { memakai } \\
\text { masker }\end{array}$ & $\begin{array}{l}\text { Pembagian } \\
\text { masker dan } \\
\text { sosialisasi }\end{array}$ & $\begin{array}{l}\text { Masyara } \\
\text { kat di } \\
\text { pasar } \\
\text { desa } \\
\text { Curugbit } \\
\text { ung }\end{array}$ & $\begin{array}{l}\text { Medso } \\
\text { s atau } \\
\text { yang } \\
\text { lainny } \\
\text { a }\end{array}$ & $\begin{array}{l}\text { RT/R } \\
\text { W/Sat } \\
\text { uan } \\
\text { Tugas } \\
\text { Covid- } \\
\text { 19) }\end{array}$ & Mandiri & $\begin{array}{l}\text { Pengisian } \\
\text { Perencana } \\
\text { an }\end{array}$ \\
\hline 5. & $\begin{array}{l}24 / 11 / \\
20\end{array}$ & $\begin{array}{l}\text { Wawancara } \\
\text { para } \\
\text { pedagang } \\
\text { tentang } \\
\text { dampak } \\
\text { covid-19 }\end{array}$ & $\begin{array}{l}\text { Wawancara } \\
\text { terdampak } \\
\text { covid }\end{array}$ & $\begin{array}{l}\text { Para } \\
\text { pedagan } \\
\text { g di } \\
\text { pasar } \\
\text { desa } \\
\text { Curugbit }\end{array}$ & $\begin{array}{l}\text { Medso } \\
\text { s atau } \\
\text { yang } \\
\text { lainny } \\
\text { a }\end{array}$ & $\begin{array}{l}\text { RT/R } \\
\text { W/Sat } \\
\text { uan } \\
\text { Tugas } \\
\text { Covid- } \\
\text { 19) }\end{array}$ & Mandiri & $\begin{array}{l}\text { Pengisian } \\
\text { Perencana } \\
\text { an }\end{array}$ \\
\hline
\end{tabular}




\section{El-Mujtama: JurnalPengabdian Masyarakat}

Vol 2 No 1 (2022) 74-91 P-ISSN2746-9794E-ISSN2747-2736

DOI: 10.47467/elmujtama.v12i1.542

\begin{tabular}{|l|l|l|l|l|l|l|l|}
\hline & $\begin{array}{l}\text { terhadap } \\
\text { ekonomi }\end{array}$ & ung & & & & \\
\hline
\end{tabular}

\section{B. Hasil Kegiatan}

1. Pendataan penduduk dilaksanakan untuk mengetahui struktur usia penduduk, jumlah penduduk berdasarkan tingkat pendidikan, dan jumlah penduduk berdasarkan pekerjaan di RT 02 .

STRUKTUR USIA PENDUDUK TINGKAT RT 02 RW 07 DESA CURUGBITUNG KECAMATAN NANGGUNG KABUPATEN BOGOR

\begin{tabular}{|c|c|c|c|c|c|c|}
\hline \multirow{2}{*}{ No } & \multirow{2}{*}{ Kelompok Usia } & \multicolumn{4}{|c|}{ Jumlah Penduduk } & \multirow{2}{*}{$\begin{array}{c}\text { Jumlah } \\
\text { Total }\end{array}$} \\
\cline { 3 - 6 } & & $\mathrm{L}$ & Persentase & $\mathrm{P}$ & Persentase & 19 \\
\hline 1. & $0-5$ Tahun & 9 & $47 \%$ & 10 & $53 \%$ & 21 \\
\hline 2. & 6-9 Tahun & 9 & $42 \%$ & 12 & $58 \%$ & 45 \\
\hline 3. & 10-24 Tahun & 30 & $45 \%$ & 25 & $55 \%$ & 78 \\
\hline 4. & 25-59 Tahun & 48 & $61 \%$ & 28 & $39 \%$ & 14 \\
\hline 5. & 60- Tahun & 8 & $58 \%$ & 6 & $42 \%$ & \\
\hline
\end{tabular}

DATA JUMLAH PENDUDUK BERDASARKAN TINGKAT PENDIDIKAN RT 02 RW 07 DESA CURUGBITUNG KECAMATAN NANGGUNG KABUPATEN BOGOR

\begin{tabular}{|c|l|c|c|c|c|c|}
\hline \multirow{2}{*}{ No } & \multirow{2}{*}{ Tingkat Pendidikan } & \multicolumn{4}{|c|}{ Jumlah Penduduk } & Jumlah \\
\cline { 3 - 6 } & & L & Persentase & P & Persentase & Total \\
\hline 1 & Tidak Sekolah & 6 & $40 \%$ & 9 & $60 \%$ & 15 \\
\hline 2 & Tamat SD & 23 & $62 \%$ & 14 & $38 \%$ & 37 \\
\hline 3 & Tamat SMP & 15 & $45 \%$ & 18 & $55 \%$ & 33 \\
\hline 4 & Tamat SMA & 27 & $57 \%$ & 21 & $43 \%$ & 48 \\
\hline 5 & $\begin{array}{l}\text { Tamat Perguruan } \\
\text { Tinggi }\end{array}$ & 3 & $60 \%$ & 2 & $40 \%$ & 5 \\
\hline & & & & & & 138 \\
\hline
\end{tabular}

DATA JUMLAH PENDUDUK BERDASARKAN PEKERJAAN RT 02 RW 07 DESA CURUGBITUNG KECAMATAN NANGGUNG KABUPATEN BOGOR

\begin{tabular}{|c|c|c|c|c|c|c|}
\hline No & Jenis Pekerjaan & \multicolumn{4}{|c|}{ Jumlah Penduduk } & Jumlah Total \\
\hline & & $\mathrm{L}$ & Persentase & $\mathrm{P}$ & Persentase & \\
\hline 1 & Tidak Bekerja & - & - & 42 & $100 \%$ & 42 \\
\hline 2 & PNS & - & - & - & - & - \\
\hline 3 & TNI/Polri & - & - & - & - & - \\
\hline 4 & Karyawan Swasta & 2 & $100 \%$ & - & - & 2 \\
\hline 5 & Pedagang Petani & 6 & $100 \%$ & - & - & 6 \\
\hline 6 & Buruh Tani & 1 & $100 \%$ & - & - & 1 \\
\hline 7 & Buruh & 10 & $100 \%$ & - & - & 10 \\
\hline 8 & Wiraswasta & 41 & $100 \%$ & - & - & 41 \\
\hline 9 & Pensiunan & 1 & $100 \%$ & - & - & 1 \\
\hline 10 & Sopir & 2 & $100 \%$ & - & - & 2 \\
\hline 11 & Penjahit & 1 & $100 \%$ & - & - & 1 \\
\hline 12 & Guru honorer & 2 & $40 \%$ & 3 & $60 \%$ & 5 \\
\hline
\end{tabular}




\section{El-Mujtama: JurnalPengabdian Masyarakat \\ Vol 2 No 1 (2022) 74-91 P-ISSN2746-9794E-ISSN2747-2736 \\ DOI: 10.47467/elmujtama.v12i1.542}

2. Penyuluhan tentang bahaya Covid-19 kepada anak-anak di lingkungan RW 07 bertujuan untuk menjelaskan dan memberikan informasi tentang apa itu Covid19 dan bahaya nya jika kita terserang virus tersebut serta agar anak-anak bisa mengetahui cara agar tidak terjangkit dan mencegah penyebaran virus tersebut di lingkungannya. Kegiatan ini dilaksanakan di rumah penulis di RT 02/07.

3. Penyuluhan tentang pentingnya menjaga kebersihan dan kesehatan di masa pandemi sekaligus berolahraga bersama dilaksanakan agar anak-anak bisa mengetahui betapa pentingnya menjaga kebersihan diri sendiri dan lingkungan sekitar di masa pandemi ini dan pentingnya menjaga kesehatan dengan berolahraga untuk menjaga dan meningkatkan kekebalan imun yang akan berimbas pada pengaruh penyebaran virus Covid-19 ini. Olahraga bersama yg dilaksanakan berupa senam ria yang sangat diminati oleh anak-anak karena menyenangkan. Kegiatan ini dilaksanakan di kediaman penulis di RT 02/07.

4. Pembagian masker dan pensosialisasian pentingnya memakai masker bertujuan agar masyarakat sadar akan bahaya Covid-19 dan pentingnya mematuhi protokol kesehatan. Kegiatan ini dilaksanakan di pasar desa Curugbitung yang biasa beroperasi setiap hari selasa dan sabtu, tempat ini dipilih karna banyak pedagang yang berasal dari luar desa Curugbitung yang bisa menjadi perantara penyebaran virus dan masih banyak masyarakat yang belum sadar ataupun abai terhadap protokol kesehatan yang telah ditetapkan pemerintah seperti memakai masker dan menjaga jarak.

5. Wawancara terhadap para pedagang di pasar desa curugbitung ini dilaksanakan untuk mengetahui seberapa berdampaknya Covid-19 terhadap perekonomian mereka, pedagang yang diwawancara diantaranya pedangan sayuran, pakaian, ikan, toserba dan toko beras.

Hasil wawancara:

Pertanyaan yang diajukan: " sejak adanya pandemi Covid-19 apakah ada yang berbeda dengan kegiatan jual beli yang bapak/ibu lakukan? Apakah Covid19 ini berdampak kepada dagangan bapak/ibu?"

1) Penjual baju

"Sangat jelas perbedaannya, dulu sebelum pandemi Covid-19 pemasukan dari dagangan ini lumayan bagus, setiap hari pasti ada yang datang untuk membeli, namun sekarang sangat menurun, hari ini saja belum ada yang membeli. Saya harap pandemi Covid-19 ini cepat membaik dan hilang dan juga ekonomi segera pulih dan bertumbuh seperti sebelum pandemi." Jelas ibu penjual baju yang saya wawancarai.

2) Penjual ikan asin

"Setelah pandemi Covid-19 sekarang pasar menjadi sepi, pemasukanpun menurun hampir 50\% dari biasanya, masyarakat kini harus menghemat dan lebih pemilih karena ekonomi sedang tidak baik."

3) Penjual Sayuran

"Saya tidak merasakan banyak perubahan ya, karena kan sayuran itu makanan pokok jadi masyarakat mau tidak mau harus membeli sayuran, laba juga tidak banyak berubah sama dengan sebelum pandemi Covid- 


\section{El-Mujtama: JurnalPengabdian Masyarakat \\ Vol 2 No 1 (2022) 74-91 P-ISSN2746-9794E-ISSN2747-2736 \\ DOI: 10.47467/elmujtama.v12i1.542}

19. Mungkin rempah-rempah yang mengalami kenaikan, karena pandemi covid 19 banyak masyarakat yang ingin memperkuat imunnya dengan mengonsumsi lebih banyak rempah-rempah seperti kunyit, jahe, dll." Jelas bapak yang saya wawancarai di pasar.

4) Warung sembako

"Menurut saya perubahan ada, namun tidak turun banyak. Karena kan masyarakat sangat membutuhkan sembako, maka dari itu saya tidak terlalu merasakan perbedaannya setelah dan sebelum pandemi Covid19." Jelas bapak yang saya wawancarai.

5) Toko Beras

"Yang saya rasakan banyak penurunan, karena walaupun beras itu makanan pokok namun sekarang karena pandemi Covid-19 banyak masyarakat yang mendapat bantuan dari pemerintah. Laba pun mengalami penurunan tidak seperti sebelum pandemi Covid-19." Jelas ibu yang saya wawancarai di toko berasnya.

\section{Analisis Masalah}

Setelah penulis mengobservasi dan menganalisis penulis menemukan bahwasannya di RW 07 desa Curugbitung masyarakatnya cenderung belum sadar akan pentingnya menerapkan protokol kesehatan saat pandemi seperti sekarang ini. Masih banyak masyarakat yang tidak memakai masker keluar rumah, berkerumun, dan menjaga kebersihan. Hal ini penulis temukan saat pergi ke pasar atau ke tempat-tempat ramai lainnya.

Namun, penulis juga menemukan bahwasannya tidak semua masyarakat acuh akan protokol kesehatan ini, masih banyak masyarakat yang patuh dalam menjalankan protokol kesehatan.

Oleh karena itu penulis memprogramkan pembagian masker gratis yang diselenggarakan pada hari selasa tanggal 24 november 2020 yang penulis harapkan dengan membagikan masker ini masyarakat sadar dengan pentingnya memakai masker ketika keluar rumah. Dan juga untuk memutus penyebaran covid19 di masyarakat desa Curugbitung.

\section{KESIMPULAN DAN SARAN}

\section{Kesimpulan}

PPM atau Program Pemberdayaan Masyarakat adalah salah satu bentuk pengabdian dari mahasiswa untuk masyarakat. Tahun ini pelaksanaan PPM berbeda dengan tahun sebelumnya karena terdampak Covid-19. PPM tahun ini bertujuan untuk memberikan kesempatan kepada mahasiwa bagaimana mahasiswa dapat berperan serta dalam membangun kesadaran masyarakat untuk pencegahan dari penularan Covid-19 dan memberi pemahaman masyarakat untuk memasuki New Normal dengan tetap mematuhi protokol kesehatan Covid-19 dan ketentuan perilaku hidup masa New Normal. 


\section{El-Mujtama: JurnalPengabdian Masyarakat \\ Vol 2 No 1 (2022) 74-91 P-ISSN2746-9794E-ISSN2747-2736 \\ DOI: 10.47467/elmujtama.v12i1.542}

Adapun kegiatan yang telah penulis kerjakan selama PPM berlangsung antara lain : pendataan penduduk, penyuluhan tentang bahaya Covid-19, pensosialisasian pentingnya menjaga kebersihan dan kesehatan di masa pandemi, pembagian masker dan memberikan informasi pentingnya memakai masker, serta wawancara perihal dampak Covid-19 terhadap ekonomi para pedagang.

\section{Saran}

1. Pemerintah

a. Pemerintah perlu berusaha lebih dalam penyuluhan terkait Covid-19 karena masih banyak masyarakat yang acuh ataupun abai terhadap protokol kesehatan karena menganggap virus Covid-19 ini hanya lah sebuah hoax, hal ini akan mempercepat penyebaran virus dan memperlambat terputusnya rantai penyebaran Covid-19. .

2. Masyarakat

a. Masyarakat sebaiknya mematuhi protokol kesehatan yang telah dianjurkan pemerintah

b. Masyarakat harus bisa bekerja sama dengan pemerintah agar rantai penyebaran virus cepat terputus dengan mempercayai bahwa virus tersebut benar-benar ada dan harus diwaspadai.

3. Untuk IAI-N LAA ROIBA

a. Diharapkan kepada kampus agar terus mengingatkan kepada mahasiswanya untuk terus mematuhi protokol yang telah dianjurkan pemerintah.

Demikian laporan PPM ini penulis buat,semoga dapat bermanfaat bagi pihak-pihak yang membutuhkan. Kami nengucapkan terimakasih kepada seluruh pihak yang terkait dan telah membantu dalam pelaksanaan PPM IAIN Laa Roiba.

DAFTAR PUSTAJA

Prodi Ekonomi Syariah. 2020. Pedoman KKN Tematik. Bogor: Eksyar Laa Roiba BPS Kab Bogor. 2020. Statistik Kabupaten Bogor. Bogor: BPS Bogor. 


\section{El-Mujtama: JurnalPengabdian Masyarakat}

Vol 2 No 1 (2022) 74-91 P-ISSN2746-9794E-ISSN2747-2736

DOI: 10.47467/elmujtama.v12i1.542 